\title{
Adaptation and Initial Validation of the Perceived Employability Scale
}

\author{
Sílvia Monteiro ${ }^{1}$ (D) https://orcid.org/0000-0002-5236-2711 \\ Adela García-Aracil ${ }^{2}$ (D) https://orcid.org/0000-0002-9745-0563 \\ Leandro Silva Almeida ${ }^{1}$ (D) https://orcid.org/0000-0002-0651-7014
}

\begin{abstract}
Our study seeks to (i) explore the factor structure of the perceived employability scale - Higher Education version; (ii) identify the biographical and contextual predictors of the perceived employability. For this purpose, 373 Portuguese graduates participated in our study. Based on collected data, we performed confirmatory factor analysis and regression analysis. The data allow to confirm a four-factor solution with a $67 \%$ total variance explained (34\% for factor $1,14 \%$ for factor $2,12 \%$ for factor 3 and $7 \%$ for factor 4), based on the theorical framework. Regarding the predictors of the perceived employability, gender and study area arose as negative predictors, while the previous work experience showed to be a negative predictor. Based on the results we can provide theorical and practical explanations regarding the evaluation and intervention in the graduates' employability.
\end{abstract}

Keywords: perceived employability, evaluation, colleges

\section{Adaptação e Validação inicial da Escala de Empregabilidade Percebida}

Resumo: Este estudo pretende (i) explorar a estrutura fatorial da escala de empregabilidade percebida - versão para o ensino superior; (ii) identificar os fatores biográficos e contextuais preditores da empregabilidade percebida. Para tal, 373 graduados portugueses participaram neste estudo. Com base nos dados recolhidos, foram conduzidas análises fatoriais confirmatórias e análises de regressão. Os dados obtidos permitem-nos confirmar uma solução de quatro fatores, baseada no quadro teórico apresentado, com uma variância total explicada de $67 \%$ (34\% para o fator 1, 14\% para o fator 2, 12\% para o fator 3 e $7 \%$ para o fator 4). Relativamente aos preditores da empregabilidade percebida, o género e a área de estudo emergiram como preditores positivos, enquanto que a experiência de trabalho prévia se apresentou como um preditor negativo. Os resultados apresentados permitem-nos tecer algumas implicações teóricas e práticas relativamente à avaliação e intervenção na empregabilidade dos graduados no ensino superior.

Palavras-chave: empregabilidade percebida, avaliação, universidades

\section{Adaptación y Validación inicial de la Escala de Empleabilidad Percibida}

\begin{abstract}
Resumen: Este estudio busca (i) explorar la estructura factorial de la escala de empleabilidad percibida -con versión para la educación superior-; e (ii) identificar los factores biográficos y contextuales que predicen la empleabilidad percibida. Para ello, en este estudio participaron 373 graduados portugueses. Con base en los datos recopilados, se realizaron análisis factoriales confirmatorios y análisis de regresión. Los datos obtenidos nos permiten confirmar una solución de cuatro factores, basada en el marco teórico presentado, con una varianza total explicada del $67 \%$ (el 34\% para el factor 1, el 14\% para el factor 2, el 12\% para el factor 3, y el $7 \%$ para el factor 4 ). Con respecto a los predictores de empleabilidad percibida, el género y el área de estudio surgieron como los predictores positivos, mientras que la experiencia laboral previa fue el negativo. Los resultados presentados nos permiten plantear algunas implicaciones teóricas y prácticas con relación a la evaluación e intervención en la empleabilidad de los graduados en educación superior.
\end{abstract}

Palabras clave: empleabilidad percibida, evaluación, universidades

${ }^{1}$ Universidade do Minho, Braga, Portugal

${ }^{2}$ Universitat Politécnica de Valencia y Consejo Superior de Investigaciones Cientificas, INGENIO (CSIC-UPV), Valencia (Spain)

The research for this paper has been also conducted as part of the research project ref. RTI2018-101722-B-I00 "SUISIA", funded by the National R\&D Programme of the Spanish Ministry of Science, Innovation and Universities. The views expressed in this paper are not necessarily the views of that organization. This work is funded by FCT (SRFH/BPD/92331/2013) and by CIEd - Research Centre on Education, project UID/CED/01661/2019, Institute of Education, University of Minho, through national funds of FCT/MCTES-PT."

Correspondence address: Sílvia Monteiro. Universidade do Minho. Centro de Investigação em Educação. Campus de Gualtar, Braga 4710-057, Portugal. E-mail: silviamonteiro@ie.uminho.pt
Graduates' employability has been studied through several perspectives in the literature. Some approaches have focused on the role of Higher Education (HE) institutions as the main determinant of employability, while other approaches have addressed the concept from an individual perspective. The firstones, frequently presented as institutional achievement, are measured through graduates' employability rates (Harvey, 2001) and represent a substantial body of the literature on graduates' employability. Nonetheless, these approaches tend to use data from large-scale surveys and to focus on labor market outcomes as an attempt to predict different trajectories of graduates (Tomlinson, 2007), disregarding the individual 
contribution to foment one's employability. This approach tends to be confined to a simplistic view of employability, which is seen as "the ability to gain and retain fulfilling work" (Hillage \& Pollard, 1998), and provides a scarce contribution to the promotion of individual resources that foster employability. On the other hand, individual approaches to employability enhance the existence of proactive characteristics that enable individuals to play an active role in their own employability. According to this perspective, a commonly cited definition of employability is the one proposed by Fugate, Kinicki, and Ashforth (2004, p. 15): "a psychosocial construct that embodies individual characteristics that foster adaptive cognition, behavior, and affect, and enhance the individual-work interface". Despite the strong focus on individual resources, this definition also suggests a narrow interaction between the individual and the environment, as a requirement to be "employable". In short, the concept of employability includes internal factors, namely vocational or job-related knowledge and skills, such as job-search abilities (Álvarez-González, López-Miguens, \& Caballero, 2017; Hillage \& Pollard, 1998; Qenani, MacDougall, \& Sexton, 2014) or the potential to learn (Lane, Puri, Cleverly, Wylie, \& Rajan, 2000), along with external factors, such as the current state of the labor market (Lane et al., 2000; Qenani et al., 2014). According to several authors, the integration of these two sets of factors are the basis of self-perceived employability (Álvarez-González et al., 2017; Rothwell, Herbert, \& Rothwell, 2008; Qenani et al., 2014; Vanhercke, De Cuyper, Peeters, \& De Witte, 2014), namely "what individuals seeking a particular type of work believe their chances of success are, and what factors influence their perceptions" (Rothwell et al., 2008, p. 1).

Although there is some consensus on the multidimensionality of self-perceived employability, and on the necessity to consider both personal and contextual factors to its operationalization, some divergence is observed concerning the number of dimensions that compose the concept (Fugate et al., 2004; Pool \& Qualter, 2013; Rothwell $\&$ Arnold, 2007). One of the instruments to measure graduates' employability is the Self-Perceived Employability Scale (SPES), developed by Rothwell et al. (2008), originally designed for college students and further tested with postgraduate students (Rothwell, Jewell, \& Hardie, 2009). This instrument is built on a conception of employability defined as "the perceived ability to attain sustainable employment appropriate to one's qualification level" (Rothwell et al., 2008, p. 2). Four interactive components are represented in the theoretical matrix that grounds this scale: (i) "My University" - potential impact of the reputation of the university attended on a student's perception; (ii) "My Field of Study" - potential impact of the differences among the vocational areas on self-perceptions of employability; (iii) "Self-Belief" - internal factors that include graduates' perceptions concerning attributes, skills, abilities and engagement with study; and (iv) "The State of the External Labor Market" - external factors such as the general state of the labor market. However, there is also theoretical support for two dimensions composing the concept of self-perceived employability, one related to internal/individual aspects and other related to external aspects inherent to employability (Heijde \& Van der Heijden, 2006; Hillage \& Pollard, 1998; Pool \& Qualter, 2013; Rothwell \& Arnold, 2007; Rothwell et al., 2008, 2009). Thus, empirical studies about the factor structure of the SPES support a four-factor solution with items organized similarly to the theoretical matrix of four components. Moreover, a two-factor solution was also shown to be possible, referring to internal/individual attributes and to external factors related to the state of the labor market (Rothwell et al., 2008, 2009).

In Portugal, the search for higher employment opportunities is currently the major reason to enroll in HE (Tavares, 2017). To our knowledge, few studies with HE samples are available (Caricati, Chiesa, Guglielmi, \& Mariani, 2016; Maiolo, Zuffo, \& Cortini, 2013; Rothwell et al., 2008, 2009), and so little is still known about the factors that underlie perceived employability, particularly on higherunemployment rates among graduates. One study in the field has shown a positive and significant correlation between real and perceived employability (Caricati et al., 2016), which justifies the importance of further studies on this construct. Moreover, exploring students' perceptions of employability can detect possible career difficulties and to develop promotion actions regarding future graduates' employability. In Portugal, job centers indicate that approximately $13 \%$ of the unemployed people registered have a HE diploma (64\% are women). This circumstance have made it particularly difficult for young graduates to enter the labor market, especially those from study fields with higher registered unemployment rates (social and behavioral sciences and business sciences, according to the Portuguese Direção Geral de Estatística da Educação e Ciência [DGEEC], 2015). Therefore, this circumstance is expected to influence students' perception of their employability, as it has been suggested in a previous study (Mäkikangas, De Cuyper, Mauno, \& Kinnunen, 2013). As referred by Rothwell etal.(2009), it is important that the scale works independent of context, which justifies our study of this measure in an international context (Rothwell et al., 2009). Considering the Portuguese scenario, it is important to develop an instrument that can assess specific individual and contextual factors underlying selfperceived employability, thus opening doors to the promotion of employability among graduates.

Some biographical and contextual aspects are important to be considered in our study. A previous study has reported that age is negatively related to employability, since as individuals become older, they tend to be perceived as less employable (De Cuyper, Mauno, Kinnunen, \& Mäkikangas, 2011; Rothwell \& Arnold, 2007; Wittekind, Raeder, \& Grote, 2010). This has been emphasized as a complex and non-linear relationship (Froehlich, Beausaert, \& Segers, 2015) that requires some caution when interpreting data. Nevertheless, the evidence justifies the negative relation expected between age and self-perceived employability. Gender differences are evident in several career outcomes, such as wages, promotions, self-employment, and occupation of executive positions, all favoring men (Álvarez, Gradín, \& Otero, 2013; Gayle, Golan, \& Miller, 2012). Concerning subjective aspects 
of career, such differences have also been reported, namely regarding theperception of careerbarriers(Shinnar, Giacomin \& Janssen, 2012) and expectations about future labor roles (Abarca, Gormaz, \& Leiva, 2012). On the other hand, women seem to obtain fewer benefits from important career experiences such as work experience, and from training leading to career advancement (Tharenou, Latimer, \& Conroy, 1994). Therefore, graduate women score lower than graduate men in self-perceived employability. In turn, work experience during HE studies has become more common (Allen \& van der Velden, 2011), which justifies the analysis of the effect of this variable on self-perceived employability. Work experience is integrated in several employability frameworks and course provision models as an important aspect with direct or indirect influence on employability (Knight \& Yorke, 2002; Pool $\&$ Sewell, 2007). Some studies have related work experience and workplace awareness to employability (Bennett, Dunne \& Carré, 1999; Silva \& Teixeira, 2013), while others have associated practical experience with the development of a sense of efficacy, enabling the application and articulation of knowledge and skills (Edwards, 2014; van Dinther, Dochy \& Segers, 2011). Lastly, given the evident differences between fields of study concerning employment rates in Portugal (DGEEC, 2015), we anticipate that graduates' perceptions of employability will also differ according to this variable.

Therefore, our study will focus on a sample of graduates from a Portuguese university at the end of their Masters' degree in three different study fields (Social Sciences, Economics, and Engineering). We seek to explore the two and the four-factor structure and to analyze the psychometric properties of this measure in the Portuguese context. Hence, our objectives are: (i) to explore the two and the four-factor structure models to define the factor structure of the SPES - Portuguese HE Form, and (ii) to identify which biographical and contextual circumstances predict self-perceived employability. We hypothesize that (H1) Age is negatively related to self-perceived employability; (H2) Self-perceived employability depends on gender (men have more positive employability self-perceptions); (H3) Selfperceived employability depends on study field (students from study fields with higher employability rates have more positive employability self-perceptions); (H4) Work experience during $\mathrm{HE}$ is positively related to self-perceived employability. These hypotheses will be explored considering the dimensions defined in the Confirmatory Factor Analysis.

\section{Method}

\section{Participants}

Data collected included 373 students ( $60 \%$ women), with an average age of 24 years $(S D=5.71)$. These participants were enrolled in second cycle courses (postgraduate or integrated master programs), with two-year duration, in accordance with the Bologna restructuring. Participants attended the final year of their master programs at a public university in the North of Portugal. The study fields represented in this sample were Economics (25\%); Social Sciences (31\%), and Engineering (44\%). Most of these participants (about 55\%) reported having work experiences. In our article, work experience refers to activities performed by students by their own initiative, not necessarily study-related. At the time the survey was implemented, none of the students had had any internship experience.

\section{Instrument}

Self-Perceived Employability Scale - Portuguese HE Form (SPES - Portuguese HE Form). The SelfPerceived Employability Scale was originally developed by Rothwell et al. (2008) for university students and later tested with post-graduate students (Rothwell et al., 2009). The items are presented in a 5-point Likert scale, from 1 (not strong) to 5 (strongest). As described in the introduction section, previous factor studies with the scale support both the two-factor (Rothwell \& Arnold, 2007; Rothwell et al., 2008) and the fourfactor solution (Rothwell et al., 2008, 2009), composed of 16 items. The reliability values previously obtained in those studies rangebetween.75 and.84.,Skewnessvaluesrangedbetween-.567 and -.100 , and kurtosis values ranged between -.699 and .879 . Two item examples are "Employers are eager to employ graduates from my university" and "I feel I could get any job as long as my skills and experience are reasonably relevant".

After obtaining the consent from the original author of the scale to use and adapt the SPES to Portuguese graduates, this instrument was translated into Portuguese by three researchers experts in the HE field, including an English native speaker. Then, this Portuguese version was analyzed and discussed with an English teacher, who worked on its back-translation into English. After the process conclusion, a small group of participants evaluate the understanding and suitability of the scale according to their own situation. All these steps were performed in agreement with the International Test Commission guidelines for test use (Muñiz, Elosua \& Hambleton, 2013), which recommend evidence of validity and equivalence of the translated form of an instrument.

\section{Procedure}

Data collection. The questionnaire was applied during the academic year of 2015/2016 in classroom. Participation was voluntary and participants signed an informed consent form after the study objectives were presented.

Data analysis. A series of PCA were conducted with IBM SPSS 23.0 software to explore the factorial solution of the SPES - Portuguese HE Form, as suggested by previous empirical and theoretical evidence (Rothwell \& Arnold, 2007; Rothwell et al., 2008, 2009). In this process, three items were suppressed due to low communalities $(<.30)$ : E1a, E1b and E4a. When analyzing the meaning of these items, Ela "I achieve high grades in relation to my studies" and E1b "I regard my academic work as top priority" represent two specific items 
that are very much related to academic involvement and, apparently, less related to employability, when compared with other items. The item E4a "A lot more people apply for my degree than there are places available" is related to students' course choice, and it is possible that some cultural differencesmayoccurin the factorsunderlying coursechoices. For example, Portuguese students' vocational choices are not solely driven by future employability expectations, which may be an explanation for the low communalities values observed in this item. The total variance explained for a forced two-factor solution was 48\% (34\% for factor 1 and $14 \%$ for factor 2), with a Kaiser-MeyerOlkin measure of sampling adequacy of .83 , and the Bartlett's test of sphericity with a significant value $\left(X^{2}=1680.94, p<.001\right)$. Regarding the forced four-factor solution, the total variance explained was $67 \%$ (34\% for factor $1,14 \%$ for factor $2,12 \%$ for factor 3 , and $7 \%$ for factor 4 ), with a Kaiser-Meyer-Olkin measure of sampling adequacy of .83, and the Bartlett's test of sphericity with a significant value $\left(X^{2}=1680.94, p<.001\right)$. Then, we proceeded to Confirmatory Factor Analyses (CFA) using AMOS 23.0 software.

\section{Ethical Considerations}

Table 1

CFA of the SPES - Portuguese HE Form

\begin{tabular}{lcccccccc}
\hline SPES- HE Form & $\mathrm{X} 2$ & $\mathrm{df}$ & $\mathrm{X} 2 / \mathrm{df}$ & $\mathrm{p}$ & $\mathrm{GFI}$ & $\mathrm{CFI}$ & RMSEA* & SRMR \\
\hline 2-factor model & 501,344 & 64 & 7.83 & $<.001$ & .820 & .744 & $.133(1.22-1.44)$ & .103 \\
4-factor model & 136,362 & 59 & 2.31 & $<.001$ & .946 & .952 & $.059(.046-.072)$ & .047 \\
Second-order four factor model & 180,886 & 65 & 2.82 & $<.001$ & .926 & .929 & $.069(.057-.081)$ & .058 \\
\hline
\end{tabular}

Note. $* 90 \%$ CI

When analyzing the two-factor solution, the statistical data obtained do not adequately support the model. The values for this solution exceed the acceptable limits of an adjusted model, namely the $X^{2} / d f$ value, higher than 5 , and the RMSEA, superior to 0.10 . Also, GFI and CFI values are below the minimum acceptable value of 0.9 (Weston \& Gore, 2006). On the other hand, our data support a four-factor solution as the most appropriate model, considering fit indices. When comparing the two possibilities for this solution, the first-order four factor model presents best fit indices than the second-order four-factor model. Nevertheless, both possibilities may be considered statistically acceptable, since they show fit indices (GFI/CFI > .90; RMSEA [.05-.10]).

Figure 1 illustrates the grouping of items in the four components and the respective standardized loadings, all higher than .6. Component 1 defined as "My University" describes items related with students' perception about the strength of the university brand. Component 2 defined as "My Study Field" consists of two items related to the status and credibility of the field of study. Component 3 defined as "External Labor Market" combines the perception about the state of the external labor market with its demand for people in that field of study. Lastly, Component 4 defined as "Self-
The University Ethics Committee approved the research project in which this study is integrated, certified its compliance with good research practice (protocol number: CEUM/019/2014 - IE).

\section{Results}

CFA were conducted to test, firstly, a two-factor solution, and secondly, a four-factor solution. Lastly, the possibility of a second-order four-factor solution was explored, since some authors have claimed that self-perceived employability may also be measured as a single factor (Hernández-Fernaud, Ramos-Sapena, Negrín, Ruiz-de la Rosa, \& Hernández, 2011; Rothwell \& Arnold, 2007; Vanhercke et al., 2014; Wittekind et al., 2010). The estimation method used to conduct CFA was the Maximum Likelihood. Table 1 shows the results concerning model fit for each tested model.
Belief' comprises self-confidence in one's skills and abilities and the awareness of opportunities in the external labor market. Generally, this four-component model is in line with the theoretical matrix proposed by Rothwell et al. $(2008,2009)$.

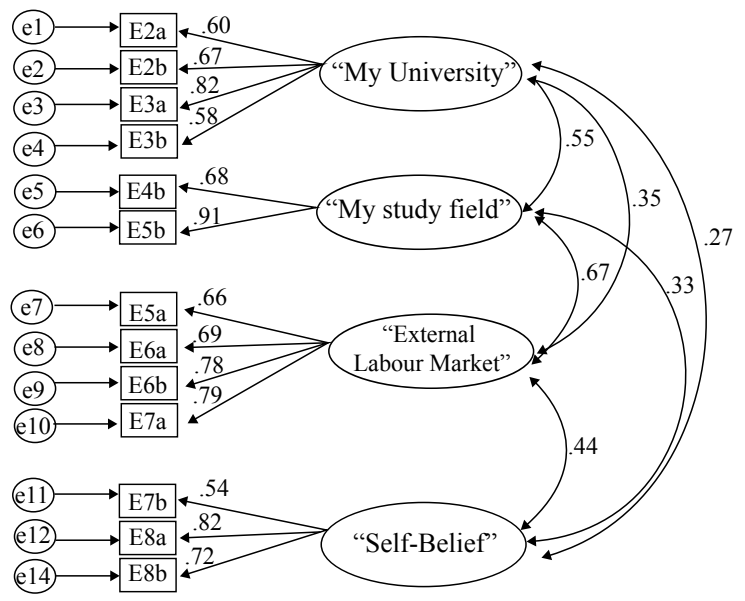

Figure 1. Four-factor solution of the CFA with standardized estimates. 
Table 2 presents descriptive statistics, correlations, and internal consistency reliability estimates of the dimensions and the total scale. Observing the descriptive values, it is possible to verify that the subscales related with the "study field" and the "external labor market" have lower scores comparing with the subscale of "my university" and "self-belief. Overall, the SPES Portuguese HE Form is moderately to strongly correlated with all the subscales. All the four dimensions of the scale are significantly intercorrelated. Concerning reliability estimates, all the values are above the acceptable value of .70 (Kline, 2013).

Table 2

Descriptive statistics, correlations, and internal consistency reliability estimates of the variables

\begin{tabular}{|c|c|c|c|c|c|c|c|}
\hline & Mean & SD & 1 & 2 & 3 & 4 & 5 \\
\hline 1.SPES - Portuguese HE Form & 3.11 & .50 & $(.80)$ & $.661 * *$ & $.756 * *$ & $.829 * *$ & $.582 * *$ \\
\hline 2.My University & 3.81 & .57 & & $(.76)$ & $.438 * *$ & $.283 * *$ & $.198 * *$ \\
\hline 3.My Study Field & 3.37 & .84 & & & $(.77)$ & $.553 * *$ & $.249 * *$ \\
\hline 4.External Labor Market & 3.05 & .80 & & & & $(.82)$ & $.338 * *$ \\
\hline 5.Self-Belief & 3.51 & .61 & & & & & $(.72)$ \\
\hline
\end{tabular}

Table 3 shows the results of the regression analyses with the standardized coefficients, R square, adjusted R square, and $\mathrm{F}$ values for the overall equations. Biographical and contextual circumstances were also integrated in the analysis, namely, gender, age, study field, and work experience. In our study, dummy variables were created for categorical variables: Gender was scored as $0=$ male (reference group), $1=$ female; study field was scored as $1=$ Economics, $2=$ Social Sciences, 3 = Engineering (reference group); and work experience was scored as $0=$ without work experience (reference group), 1 = with work experience.

Generally, the considered predictors seem irrelevant for the explanation of variance of the dimension "My University", but have a significant contribution to the other measures: approximately 19\%, 26\%, 2\%, and 18\% to "My Study Field",
"External Labor Market" and "Self-Belief", respectively. Concerning gender, being a female graduate is a negative predictor of the dimensions "My Study Field", "External Labor Market" and "Self-Belief", which confirms H1. Contrarily to H2, age shows no predictive influence on any dimensions. "Study Field" is a significant predictor of the dimensions "My University", "My Study Field" and "External Labor Market", which supports H3. In turn, work experience during HE is a negative predictor of selfperceived employability, taking the "External Labor Market" subscale. Such result discards H4, since it was anticipated that work experience would affect positively the selfperceived employability, especially because individuals with work experience were expected to have a higher awareness of the labor market.

Table 3

Beta weights of predictors of the four dimensions of the SPES-Portuguese HE Form

\begin{tabular}{|c|c|c|c|c|}
\hline Predictor & My University & My Study Field & External Labor Market & Self-Belief \\
\hline Age & -.009 & .008 & -.023 & .014 \\
\hline $\begin{array}{l}\text { Gender } \\
\text { Female }\end{array}$ & -.022 & $-.114 *$ & $-.127 *$ & $-.176^{*}$ \\
\hline \multicolumn{5}{|l|}{ Study Field } \\
\hline $\begin{array}{l}\text { Economics } \\
\text { Social Sciences }\end{array}$ & $\begin{array}{l}-.044 \\
-.048\end{array}$ & $\begin{array}{c}-.075 \\
-.394 * *\end{array}$ & $\begin{array}{l}-.195 * * \\
-.432 * *\end{array}$ & $\begin{array}{l}.003 \\
-.040\end{array}$ \\
\hline With work experience & -.083 & -.068 & $-.133^{*}$ & .025 \\
\hline R square & .014 & .201 & .272 & .038 \\
\hline Adjusted R square & .000 & .190 & .262 & .024 \\
\hline F for overall equation & 1.026 & $17.984 * *$ & $26.740 * *$ & $2.808 *$ \\
\hline
\end{tabular}

Note. Significance levels: ${ }^{*} p<0.05 ; * * p<0.001$.

\section{Discussion}

We sought to explore the factorial structure of a Portuguese version of the SPES for HE, originally developed by Rothwell et al. (2008, 2009), and to identify some biographical and contextual circumstances that may interfere with self-perceived employability.

Data from the CFA allowed to support the four-factor solution grounded in the theoretical framework proposed by Rothwell et al. (2008, 2009). On the other hand, the two- 
solution model initially hypothesized based on theoretical evidence did not obtain satisfactory fit indices in the CFA.

The presented 13-item model showed adequate internal consistency, as well as fit indices that comprise the four dimensions anticipated by the original authors for the measure of self-perceived employability in HE populations: (i) "My University"; (ii) "My Study Field"; (iii) External Labor Market"; and (iv) Self-Beliefs. This means that, altogether, university brand, study field, external labor market, and self-beliefs describe graduates' perceptions about their employability. The weak communality values observed with the two items that were supposed to specifically measure graduates' perceptions of academic engagement ("I achieve high grades in relation to my studies" and "I regard my academic work as top priority") indicates that engagement with studies apparently does not relate to the other items that compose this measure of self-perceived employability. This possibility has been raised previously in Rothwell's 2009 study, now supported with our study.

Concerning the descriptive statistics of the different dimensions of the SPES, it seems that participants are more pessimistic about contextual circumstances of employability than regarding their own abilities to operate in the Labor Market (self-efficacy subscale). This result may be a consequence of the specific Portuguese context, which is particularly difficult for the newcomers to the labor market, and characterized by distinct opportunities depending on the study field. Further studies in different socioeconomic contexts should explore these differences among the subscales to confirm this possible relation.

Contrarily to what was theoretically hypothesized, age did not appear as a predictor of self-perceived employability. This finding suggests that age may have a different relation with self-perceived employability among graduates than it has among employees. Nevertheless, it is also possible that the age variance in our sample is not large enough to enhance such relation. Studies with a more heterogeneous sample should explore the association between graduates' age and self-perceived employability, for example, among different education levels (e.g., graduate and post-graduate students). As recently argued by Froehlich et al. (2015), age is a proxy measure for many changes related to aging and it can be difficult to separate age from other effects. Therefore, further empirical studies should address this question to clarify this relation.

The influence of gender on self-perceived employability was confirmed, as initially predicted. The component "My University" was the only subscale that did not reflect this influence, which seems logical, given that the four items composing these dimensions set aside any type of personal characteristics or influence in employability. This result demonstrates that gender differences in employability are evident since early stages, even before graduates' transition from university to labor market. In turn, work experience negatively influences the dimension related to the perception of the external labor market and to the total SPES-HE Portuguese Form. Work experience seems to make graduates more pessimistic about their own employability. This may sound somewhat inconsistent with previous studies that relate work experience to workplace awareness, which is supposed to positively influence employability (Bennett et al., 1999). Moreover, a previous study has suggested that gender differences become visible starting with the first work experiences during HE studies. It seems that the contact with professional contexts makes women more aware of gender discrimination (Monteiro, Almeida, \& Garcia-Aracil, 2016). Thus, a possible explanation for this negative relation between work experience and these measures of selfperceived employability is that work experiences may have a negative impact on the perception of employability for graduate women. However, the nature of the work experiences (study-related or not study-related) considered in the analysis and their duration (short-time or long-time experiences) were not analyzed. The differentiation of work experiences may have influenced these results. From a practical viewpoint, the immediate conclusion enhances the importance of being aware and to preventively intervene in gender differences in professional contexts, even before the transition to the labor market. Gender disparity concerning self-beliefs is particularly worrying, since it has been a domain clearly related to future employability and career success (Blustein, 2006; Pinquart, Juang, \& Silbereisen, 2003; Pool \& Sewell, 2007; Turner, 2014).

Lastly, as expected, "study field" is a contextual factor with an impact on graduates' perceptions of employability, and this difference is more evident among Social Sciences (lower scores) and Engineering (higher scores) fields, especially for the dimensions "My Study Field" and "External Labor Market". This finding is coherent with general indicators of employability in the current Portuguese labor market, which shows higher rates of unemployment among Social Sciences than Engineering graduates (DGEEC, 2015). This demonstrates that graduates are aware of different opportunities depending on the study field they pursue.

Theoretical and practical contributions may be enhanced from this work. The availability of a self-perceived employability scale for a context, in which the young graduates are currently going through difficulties may be a powerful tool for the understanding of the employability' perceptions in such scenarios. The results evidenced that students perceive the adversity of the labor market, particularly those from study fields with lower employability rates. Our study is important due to several reasons. Firstly, it may be useful for the development and deepening of graduates' employability models and for the understanding of the relation with other variables in future works, namely those associated with the internal resources that facilitates work transition. Secondly, self-perceived employability scale can be a useful tool for evaluation of Higher Education programs and actions. Thirdly, our findings allow the planning of intervention actions for specific publics such as worker students, aiming at promoting opportunities for reflection and capacity to transfer the acquired knowledge to other contexts. Also, programs of 
career management could be particularly useful for graduates from study fields with higher unemployment, seeking to promote abilities to innovate or to transfer knowledge to areas with higher market opportunities.

One limitation of this study is the fact that only one university was considered, which particularly limits the analysis of the dimension "My University". The integration of graduates from different Portuguese university contexts would improve the understanding of the relation between this dimension with the others, and also with self-perceived employability in general.

Although the data showed in our study indicate that SPES-HE Portuguese Form may be considered a useful measure to study employability among graduates, further studies should explore its external validity, namely, the relation of this measure with other measures that have been theoretically pointed as relevant in the field. Also, the possibility of developing a few additional items should be considered, in particular to the dimension "My Study Field", to strengthen the psychometric strength of this measure. Furthermore, a follow-up study, setting a longitudinal design that incorporates objective measures of employability could offer interesting visions about how self-perceived employability determinates medium-to-long term career pathways. The exploration of self-perceived employability among diverse education levels and different stages of competency development is also a suggestion to encourage researchers in the field, which may be helpful to drive practical educative decisions.

\section{References}

Abarca, N., Gormaz, N., \& Leiva, P. I. (2012). Expectativas de roles futuros de estudiantes universitarios en Chile [Future role expectations of undergraduate Chilean students]. Universitas Psychologica, 11(2), 405-414. Retrieved from http://www.scielo.org.co/pdf/rups/v11n2/v11n2a05.pdf

Allen, J., \& van der Velden, R. (Eds.). (2011). The flexible professional in the knowledge society: General results of the Reflex Project. Dordrecht, Netherlands: Springer.

Álvarez, G., Gradín, C., \& Otero, M. S. (2013). Selfemployment: Transition and earnings differential. Revista de Economía Aplicada, 21(62), 61-90. Retrieved from https://www.redalyc.org/html/969/96928241003/

Álvarez-González, P., López-Miguens, M. J., \& Caballero, G. (2017). Perceived employability in university students: Developing an integrated model. Career Development International, 22(3), 280-299. doi:10.1108/CDI-08-2016-0135

Bennett, N., Dunne, E., \& Carré, C. (1999). Patterns of core and generic skill provision in higher education. Higher Education, 37(1), 71-93. doi:10.1023/A:1003451727126

Blustein, D. L. (2006). The psychology of working: A new perspective for career development, counseling, and public policy. Mahwah, NJ: Lawrence Erlbaum.
Caricati, L., Chiesa, R., Guglielmi, D., \& Mariani, M. G. (2016). Real and perceived employability: A comparison among Italian graduates. Journal of Higher Education Policy and Management, 38(4), 490-502. doi:10.1080/1360080X.2016.1182668

De Cuyper, N., Mauno, S., Kinnunen, U., \& Mäkikangas, A. (2011). The role of job resources in the relation between perceived employability and turnover intention: A prospective two-sample study. Journal of Vocational Behavior, 78(2), 253-263. doi:10.1016/j.jvb.2010.09.008

Direção Geral de Estatística da Educação e Ciência. (2015). Caracterização dos desempregados registados com habilitação superior [Unemployment caracterization of the Portuguese graduates]. Lisboa, Portugal: Autor. Retrieved from http://www.dgeec.mec.pt/np4/92/

Edwards, M. (2014). The impact of placements on students' selfefficacy. HigherEducation, Skills and Work-Based Learning, 4(3), 228-241. doi:10.1108/HESWBL-05-2014-0015

Froehlich, D. E., Beausaert, S. A. J., \& Segers, M. S. R. (2015). Age, employability and the role of learning activities and their motivational antecedents: A conceptual model. The International Journal of Human Resource Management, 26(16), 2087-2101. doi:10.1080/09585192.2014.971846

Fugate, M., Kinicki, A. J., \& Ashforth, B. E. (2004). Employability:Apsycho-social construct, its dimensions, and applications. Journal of Vocational Behavior, 65(1), 14-38. doi:10.1016/j.jvb.2003.10.005

Gayle, G.-L., Golan, L., \& Miller, R. A. (2012). Gender differences in executive compensation and job mobility. Journal of Labor Economics, 30(4), 829-871. doi: $10.1086 / 666615$

Harvey, L. (2001). Defining and measuring employability. Quality in Higher Education, 7(2), 97-109. doi:10.1080/13538320120059990

Hernández-Fernaud, E., Ramos-Sapena, Y., Negrín, F., Ruizde la Rosa, C. I., \& Hernández, B. (2011). Empleabilidad percibida y autoeficacia para la búsqueda de empleo en universitarios [Perception of employability and selfefficacy for job seeking in university students]. Revista de Psicología del Trabajo y de las Organizaciones, 27(2), 131-142. doi:10.5093/tr2011v27n2a5

Heijde, C. M. Van Der, \& Van der Heijden, B. I. J. M. (2006). A competence-based and multidimensional operationalization and measurement of employability. Human Resource Management, 45(3), 449-476. https:// doi.org/10.1002/hrm.20119

Hillage, J., \& Pollard, E. (1998). Employability: Developing a framework for policy analysis. London, United Kingdom: DfEE.

Kline, P. (2013). Handbook of psychological testing. London, United Kingdom: Routledge. 
Knight, P. T., \& Yorke, M. (2002). Employability through the curriculum. Tertiary Education and Management, 8(4), 261-276. doi:10.1080/13583883.2002.9967084

Lane, D., Puri, A., Cleverly, P., Wylie, R., \& Rajan, A. (2000). Employability: Bridging the gap between rhetoric and reality: Employee's perspective. London, United Kingdom: Create.

Maiolo, M. E., Zuffo, R. G., \& Cortini, M. (2013). Students' academic performance and employability: A study on Italian undergraduates. The International Journal of Learning in Higher Education, 19(4), 49-60. doi:10.18848/1447-9494/CGP/v19i04/48669

Mäkikangas, A., De Cuyper, N., Mauno, S., \& Kinnunen, U. (2013). A longitudinal person-centred view on perceived employability: The role of job insecurity. European Journal of Work and Organizational Psychology, 22(4), 490-503. doi:10.1080/1359432X.2012.665230

Monteiro, S., Almeida, L., \& Garcia-Aracil, A. (2016). Graduates' perceptions of competencies and preparation for labour market transition: The effect of gender and work experience during higher education. Higher Education, Skills and Work-Based Learning, 6(2), 208-220. doi:10.1108/HESWBL-09-2015-0048

Muñiz, J., Elosua, P., \& Hambleton, R. K. (2013). Directrices para la traducción y adaptación de los tests: Segunda edición [International test commission guidelines for test translation and adaptation: Second edition]. Psicothema, 25(2), 151-157. doi:10.7334/psicothema2013.24

Pinquart, M., Juang, L. P., \& Silbereisen, R. K. (2003). Selfefficacy and successful school-to-work transition: A longitudinal study. Journal of Vocational Behavior, 63(3), 329-346. doi:10.1016/S0001-8791(02)00031-3

Pool, L. D., \& Qualter, P. (2013). Emotional self-efficacy, graduate employability, and career satisfaction: Testing the associations. Australian Journal of Psychology, 65(4), 214-223. doi:10.1111/ajpy.12023

Pool, L. D., \& Sewell, P. (2007). The key to employability: Developing a practical model of graduate employability. Education + Training, 49(4), 277-289. doi:10.1108/00400910710754435

Qenani,E., MacDougall,N., \& Sexton, C. (2014).Anempirical study of self-perceived employability: Improving the prospects for student employment success in an uncertain environment. Active Learning in Higher Education, 15(3), 199-213. doi:10.1177/1469787414544875

Rothwell, A., \& Arnold, J. (2007). Self-perceived employability: Development and validation of a scale. Personnel Review, 36(1), 23-41. doi:10.1108/00483480710716704
Rothwell, A., Herbert, I., \& Rothwell, F. (2008). Self-perceived employability: Construction and initial validation of a scale for university students. Journal of Vocational Behavior, 73(1), 1-12. doi:10.1016/j.jvb.2007.12.001

Rothwell, A., Jewell, S., \& Hardie, M. (2009). Self-perceived employability: Investigating the responses of postgraduate students. Journal of Vocational Behavior, 75(2), 152-161. doi:10.1016/j.jvb.2009.05.002

Shinnar, R. S., Giacomin, O., \& Janssen, F. (2012). Entrepreneurial perceptions and intentions: The role of gender and culture. Entrepreneurship: Theory and Practice, 36(3), 465-493. doi:10.1111/j.1540-6520.2012.00509.x

Silva, C. S. C., \& Teixeira, M. A. P. (2013). Experiências de estágio: Contribuições para a transição universidadetrabalho [Internship experiences: Contributions to the school-to-worktransition].Paidéia(RibeirãoPreto), 23(54), 103-112. doi:10.1590/1982-43272354201312

Tavares, O. (2017). The role of students' employability perceptions on Portuguese higher education choices. Journal of Education and Work, 30(1), 106-121. doi:10.1080/13639080.2015.1122180

Tharenou, P., Latimer, S., \& Conroy, D. (1994). How do you make it to the top? An examination of influences on women's and men's managerial advancement. The Academy of Management Journal, 37(4), 899-931. doi: $10.2307 / 256604$

Tomlinson, M. (2007). Graduate employability and student attitudes and orientations to the labour market. Journal of Education and Work, 20(4), 285-304. doi:10.1080/13639080701650164

Turner, N. K. (2014). Development of self-belief for employability in higher education: Ability, efficacy and control in context. Teaching in Higher Education, 19(6), 592-602. doi:10.1080/13562517.2014.901951

Van Dinther, M., Dochy, F., \& Segers, M. (2011). Factors affecting students' self-efficacy in higher education. Educational Research Review, 6(2), 95-108. doi:10.1016/j.edurev.2010.10.003

Vanhercke, D., De Cuyper, N., Peeters, E., \& De Witte, H. (2014). Defining perceivedemployability:Apsychological approach. Personnel Review, 43(4), 592-605. doi:10.1108/PR-07-2012-0110

Weston, R., \& Gore, P. A., Jr. (2006). A brief guide to structural equation modeling. The Counseling Psychologist, 34(5), 719-751. doi:10.1177/0011000006286345

Wittekind, A., Raeder, S., \& Grote, G. (2010). A longitudinal study of determinants of perceived employability. Journal of Organizational Behavior, 31(4), 566-586. doi:10.1002/job.646 
Silvia Monteiro is a Researcher at the Research Centre on Education, Instituto de Educação, Universidade de Minho, Braga, Portugal.

Adela García-Aracil is Scientific Researcher at the Spanish National Research Council (CSIC) working at INGENIO (CSIC-UPV)

Leandro S. Almeida is a Full Professor of the Instituto de Educação, Universidade de Minho, Braga, Portugal.

\section{Authors' Contribution:}

All authors made substantial contributions to the conception and design of this study, to data analysis and interpretation, and to the manuscript revision and approval of the final version. All the authors assume public responsibility for the content of the manuscript.

Received: Jan. 22, 2018

1st Revision: May. 09, 2018

Approved: May. 29, 2018

How to cite this article:

Monteiro, S., García-Aracil, A., \& Almeida, L. S. (2019). Adaptation and initial validation of the perceived employability scale. Paidéia (Ribeirão Preto), 29, e2935. doi: http://dx.doi.org/10.1590/1982-4327e2935 